\title{
Development of Learning Model Using Learning Social Network
}

\author{
Rahayu Retnaningsih ${ }^{1}$, Marsigit $^{2}$, Supriyoko $^{3}$ Heri Nurdiyanto ${ }^{4}$ \\ wasisrahayu18@gmail.com ${ }^{1}$, herinurdiyanto@gmail.com ${ }^{4}$ \\ ${ }^{1234}$ Universitas Negeri Yogyakarta, Yogyakarta, Indonesia.
}

\begin{abstract}
The objective of the research is to produce a flipped classroom-based learning system using flipped classroom by social network learning media to overcome the limitations of time allocation of learning packaged in the form of Learning Design. The development procedure is based on the ASSURE development model through 8 stages. The learning product has been validated with the average score $(85.63 \%)$ and tested on 30 students with the average value of test result $(81,35 \%)$, concluded the product developed valid and feasible to be implemented in the learning.
\end{abstract}

Keywords: Development of learning, flipped classroom, Edmodo, ASSURE, learning social network.

\section{Introduction}

The development of the final technology this end many found the type of system social with the high-level event. The height the construction of such social networks marked by the appearance of these sites new social media popping up like facebook, twitter, path, psychology, Einstein, moodle, remix learning, Einstein, Sophia and Edmodo with the number of users is quite a lot. No little research shows effectiveness and Efficiency of social media in the learning process, not all social media can use in learning because the system is needed delivery that is not like on generally for learning using social media. One of educational, social networking is Edmodo[1].

Many types of web media are has been created and applied within learning, but not everything can be awakened motivation to learn and can fulfill student learning needs vary. Degeng states that the election of a learning media directly can be attributed to effort improve student learning motivation. So that Edmodo web media is selected as an integrated medium in development research this learning to review student's motivation to study[2]. The reason for Edmodo's media selection because; First, Edmodo is one of a kind of web that belongs learning social network ie educational social networking, or utilization of deep social networks learning because it has feature features the educative supports learning. Second, Elements learning such as assignment, presentation of the material, until evaluation at all conventional classes facilitated by educative features in Edmodo's virtual classroom. Third, Edmodo included today's social networking Its development is very rapid with users very much and already familiar used many students, so their initial ability in operating social media will facilitate the process learning using Edmodo and expected to be motivated within learn as it uses new learning experience[3]. Fourth, based on research results Edmodo web represents technology in learning-based web that offers speed access and unlimited places and time to access information, learning activities can be done students anywhere and anytime, limit space, time and distance no longer becoming a 
problem. Fifth, Edmodo web is not only accessible via laptop or computer only, but today web Edmodo already has an app which can be downloaded by Android through the web application service provider such as the Google Store, Play Store, and etc [4]. Learning becomes more fun as it can be done using the device mobile like PDAs, mobile phone, laptops and other technological tools for learning. Sixth, based on research results Mahfuddin Edmodo as fun online web and provide a new experience within learn. Learning social network type Edmodo does not necessarily used in learning at classroom [5]. It takes a design or design for learning integrating social learning network can take place on a optimal. The process of designing activities learning is called by design flipped based learning system classroom using learning social network. This research using system design flipped based learning classroom using learning social network media model ASSURE on the grounds that: The first model is capable creating learning activities which is effectively related to time and efficient with regard to cost, especially on learning activities which uses media and technology [6]. Second ASSURE model provides the process systematic (six steps) to creating a learning experience for learners. Third very appropriate to use, given the distinctive features of the model ASSURE is integrate use of media and technology in learning. Results of material analysis at the time early observation of biology subjects, learning process using traditional systems with numbers confined meetings and practice-oriented [7]. Taught at high school level and demanding the ability of students to have considerable competence Process learning is carried out for 9 meetings and meetings done for 2x55 minutes. The time limitations are felt short enough to master competencies to be achieved by students when relying only on face-to-face meetings in the classroom[8].

The effectiveness of a lesson can be improved if the teacher uses media that matches the learning content. Degeng states that there are three components in prescribing a delivery strategy; (1) learning media, (2) si-learning interaction with media and (3) form/structure of learning and teaching. Noting the problems in Setyosari and learning asserted that teachers should continue to improve the quality of learning through a variety of activities including (1) increasing commitment to quality improvement learning; (2) designing systematic learning, and (3) empower technology and media learning in the classroom[9]. Based on the above statement, improve the quality of learning by designing a learning activity systematically by empowering the progress of media and technology becomes one of the solutions in solving the problem of lack of time allocation in every lesson. Media can be printed, web-based, software and audiovisual. This research focuses on web-based that is media that provide information on the internet and used for learning[10]. The quality of web media lies in the accuracy of the material provided and also the attractiveness of the design interface. Development or utilization of the web in need of learning is called web-based learning. The motivation in this study is reviewed using the developed ARCS approach by Keller. In ARCS model four main aspects become an indicator of student motivation that is aspects of Attention, Relevance, Confidence, and Satisfaction[11]. These four aspects will be broken down into sub-indicators to review student motivation towards learning-based social network learning. This study provides a solution to the limitations allocation of learning time to achieve all the standards of competence or learning objectives that must be mastered[12]. Also to see if students motivated in following learningbased social network learning, whether the ASSURE model can create a learning experience for students, and whether a flipped classroom-based learning system using learning social network media makes it easier for students to learn theory and practice[13]. 


\section{Method}

The research and development procedure is based on the model of developing the learning system based on flipped classroom using media learning social network ASSURE with 6 stages: 1) analyze the students (characteristics, initial ability, and learning style); 2) establish learning objectives; 3 ) choose the appropriate media, methods, and materials for learning; 4) using the media, methods, and materials in learning; 5) encourage student participation in learning; 6) evaluation or repair. This study integrates the method web facilitated learning is the use of the web in learning to help mastery of unfulfilled teaching materials on face-to-face process, giving additional material through web technology and more utilization on the assignment and evaluation, with some considerations that one of them is to be tailored to the characteristics of the course will be developed, also the availability of support facilities in the form of internet network on campus. The study was conducted eight times since January-April 2018 in two subjects with 95 test subjects.

\section{Result}

Before tested to students, products and instruments are validated first by the experts (validator) to know the quality of products that have been developed. from the results of the validation of experts stated that the products and instruments are developed has been valid since the value of the given value of the validator exceeds the specified standard value. The average value of the validation result is $85.63 \%$ valid criteria, so it is concluded that the product is feasible to be tested after a small revision of the product. The subjects of the experiment were 95 students of Senior High School Students 1 Klaten, Trial did for knowing: 1) the effectiveness of the system flipped classroom-based learning social network, 2) lack which has not been detected at the moment product development and 3) so far which is a learning-based system flipped classroom using media This learning social network makes it easy for students within learning, either individually, small group or more scale broad.From the overall data test results in the graph, the average value obtained for test results of $81.30 \%$ criteria valid, so the system concluded flipped classroom-based learning use valid learning social network media for implemented both for learning individuals, small groups as well scale. System development flipped classroom-based learning using learning social network based media learning social network is said successful if after implemented a positive impact on student learning motivation is accompanied by an increase in test results learning. Student motivation is reviewed using ARCS approach with more formerly developed that instrument can measure all four aspects, i.e., attention, relevance, confidence, and satisfaction. Once validated instrument in the form of a questionnaire distributed to 24 students. The result of instrument data analysis motivation shows the value of acquisition amounted to $83.16 \%$ perfect criteria, so the system concluded flipped classroom positive toward student learning motivation. Implementation of learning at classes are observed and assessed by a person observer. Results of data analysis show the value for each aspect, namely: 1) the suitability of step in learning system with stages ASSURE (90\%), 2) student interaction $(87.5 \%)$ and 3 ) teacher reactions $(100 \%)$. The average of the final value is $91.30 \%$ goes in very criteria well, so the system concluded flipped classroom is implemented very good in class during learning. Interviews with teachers and students are done to get the data which is more accurate and convincing the validity of the data obtained if there is still data not yet obtained from data collection previous. Informant selection process did randomly avoid 
inner subjection give an opinion. From the results of the joint interview teachers, it can be concluded that the system flipped classroom using Edmodo media after being implemented for research in the classroom, got a response positive from the subject teachers. Flipped based learning system classroom considered to have varied in learning and helping the role of teachers in learning activities. On Course Learning Course, learning social Edmodo can be used as a facility for teaching all the characteristics of student learning. Teachers agreed to the implementation flipped based learning system classroom using learning social network media Edmodo performed extensively on other courses, not limited to the eyes lectures that discuss theory and practice. The weakness of Edmodo moment Implementation of learning can resolve by enabling class groups Whatsapp as an interaction event student discussion. From the interview with several students, it can be concluded that the learning system is based flipped classroom using media learning social network Edmodo after implemented during research at class, get a positive response from students as a subject of research trials. Learning using Edmodo felt close to the learning conditions the ideal, which is where learning they can be relaxed, serious but focused, active learning, friendly teacher, no atmosphere tense and learning can be anywhere and anytime. Average previous students already used the web in learning, so they do not find it difficult and make them eager to learn. Their learning spirit supported by Edmodo's role makes it easier for them to learn because material access can be done anywhere and anytime. Motivation to learn they increase because of learning that can happen anywhere, ability to be the best as it should be rated directly by friends and teachers, task collection should not be late because it will be direct caught by other students and teachers on Edmodo system

\section{Conclusion}

After the product is validated and tested, try to get some revision related to product development. Revisions are made to aspects of the physical appearance of the book reference instructions and on the design of a flipped classroom-based learning system using learning social network media about the number of destinations specified. Some revisions are made by the consideration of the validator as an attempt to improve the product development. Study of learning system based on flipped classroom using learning social network media include: 1) study of product's equity with e-learning function, 2) assessment of product compatibility with theoretical support of learning system based on flipped classroom using learning social network media, 3) study completeness components of the product to be said as a flipped classroom-based learning system using learning social network media. The conclusion of this research development can answer the purpose of the holding of research this development, namely: a) flipped classroom-based learning system using learning social network media successfully developed using ASSURE development model and generated a flipped classroom-based learning system using learning social network media and has been implemented in the class in learning process and get positive response both from teacher and student.b) learning during learning has a positive impact on student learning outcomes and motivation. There are improvements in terms of attention, relevance, confidence, and satisfaction in learning the students. c) ASSURE model used in flipped classroom-based learning system using learning social network media based on learning social network proved able to provide a new learning experience for students. d) flipped classroom-based learning system using learning social network media using ASSURE model design is proven to be easy teachers in evaluation, monitoring, and sharing of information, while for the students can help in meet their learning needs in terms of accessing materials and 
collecting tasks. e) flipped classroom-based learning systems using learning social network media using model design ASSURE is able to assist students and teachers in both theoretical and practical learning. f) flipped classroom-based learning system using learning social network media using ASSURE model design is helpful the achievement of all competencies / goals in the course Media Learning and Learning Models that must be mastered students for one semester. From the results of product development that has been produced, it can be concluded that the development product of flipped classroom-based learning system using learning social network media with model design ASSURE can be an alternative source of learning and also a new way of doing learning that can provide a new learning experience for the student. Although the test questionnaire shows that the resulting product development is appropriate with the learning needs of teachers and students, but there are still many aspects that can be developed. Some development suggestions are: a) developing content of Parents features that have not been developed in this study. This is to facilitate the reporting of student achievement of their parents / guardian as an evaluation material at lower education level. b) utilization of Planner feature to schedule learning activities agenda maximized. c) the use of email notifications used as Edmodo accounts are synced on their respective gadgets so that notifications can be received instantly like email notifications. e) further research on the effect or effectiveness of the use of learning products is suggested.

\section{References}

[1] C. Fry, M. Plusch, and H. Lieberman, "Static and dynamic semantics of the Web," Spinn. Semant. Web Bringing World Wide Web to its Full Potential, pp. 377-401, 2003.

[2] G. Plumley, Website Design and Development 100 Questions to Ask Before Building a Website. 2010.

[3] R. H. Hall, S. E. Watkins, and V. M. Eller, "A Model of Web-Based Design for Learning," Rolla, 2002.

[4] W. G. Ford, "Evaluating the Effectiveness of College Web Sites for Prospective Students," J. Coll. Admiss., vol. 212, no. 2001, pp. 26-31, 2011.

[5] A. Weinberger, I. Kollar, Y. Dimitriadis, K. M, and F. Fischer, "Technology-Enhanced Learning," Media, no. Grenoble 1, pp. 3-19, 2009.

[6] D. Buckingham, "Media education goes digital: An introduction," Learning, Media and Technology, vol. 32, no. 2. pp. 111-119, 2007.

[7] H. Nurdiyanto, "A work-based learning model with technopreneurship," Glob. J. Eng. Educ., vol. 20, no. 1, pp. 75-78, 2018.

[8] D. Napitupulu et al., "Analysis of Student Satisfaction Toward Quality of Service Facility," in Journal of Physics: Conference Series, 2018, vol. 954, no. 1.

[9] A. S. Ahmar et al., "Lecturers' understanding on indexing databases of SINTA, DOAJ, Google Scholar, SCOPUS, and Web of Science: A study of Indonesians," in Journal of Physics: Conference Series, 2018, vol. 954.

[10] L. Luo, "Software testing techniques," Inst. Softw. Res. Int. Carnegie Mellon Univ. Pittsburgh, PA, vol. 15232, no. 1-19, p. 19, 2001.

[11] J. W. Warren, "Innovation and the future of e-books," Int. J. B., vol. 6, no. 1, pp. 159$166,2011$.

[12] N. M. Foasberg, "Adoption of E-Book Readers Among College Students: A Survey," Inf. Technol. Libr., vol. 30, no. 3, pp. 108-128, 2011.

[13] J. Casey and P. Wilson, A practical guide to providing flexible learning in further and higher education. Scotland: the Quality Assurance Agency for Higher Education (QAA), 2005. 